\title{
RECOGNITION OF THE OTHER AS A REAL FREEDOM \\ IN FICHTEAN PHILOSOPHICAL THOUGHT
}

\author{
EL RECONOCIMIENTO DEL OTRO COMO UNA \\ LIBERTAD REAL EN EL PENSAMIENTO FILOSÓFICO \\ DE FICHTE
}

\author{
Héctor Oscar ARRESE IGOR* \\ Centro de Investigaciones Filosóficas, \\ Consejo Nacional de Investigaciones Científicas y Técnicas \\ (Argentina)
}

\begin{abstract}
AвSTRACT: Este trabajo apunta a mostrar que la teoría fichteana del reconocimiento del otro acarrea consecuencias importantes para la teoría de la propiedad. Fichte une íntimamente las ideas de la libertad y de la propiedad de los medios básicos para la subsistencia. A fin de mostrar este vínculo, se reconstruye la deducción de la propiedad a partir del principio del derecho. Asimismo, se desarrolla la idea de una división social del trabajo planificada centralmente por el Estado. Finalmente, se establecen relaciones entre la idea fichteana de un derecho a la subsistencia y el debate en torno de la libertad real y la libertad formal.
\end{abstract}

Dirección electrónica: harreseigor@gmail.com. Dirección postal: Miñones 2073 (C1428ATE). Ciudad de Buenos Aires. (Argentina). El autor es Investigador Adjunto del Consejo Nacional de Investigaciones Científicas y Técnicas. Se desempeña como Profesor Titular Ordinario de Filosofía Social en la Universidad Nacional de La Plata y como Profesor Asociado Ordinario de Filosofía de los Siglos XIX y XX en la Universidad Pedagógica Nacional. Este artículo pudo ser llevado a cabo gracias a los proyectos "Derechos constitutivos, libertad y propiedad en el republicanismo moderno y contemporáneo" (PIP CONICET 11220150100230CO) y "Poder político y formación ciudadana en la filosofía de Johann Gottlieb Fichte" (PICTO No 0016, Agencia Nacional de Promoción Científica y Tecnológica y Universidad Pedagógica Nacional). 
Palabras Clave: derecho, libertad, propiedad, Fichte, mercado.

АвsтRACт: This paper aims to show that the Fichtean theory of recognition of the other carries important consequences that are relevant to the theory of property. Fichte intimately links the ideas of freedom and property as the basic means for subsistence. In order to show this link, the deduction of property is reconstructed from the principle of law. Furthermore, he develops an idea of a social division of labor centrally planned by the state. Finally, the paper includes the relationships established between the Fichtean idea of a right to subsistence, and the debate about formal freedom and real freedom.

KeYwords: Law, Freedom, Property, Fichte, Market.

\section{The recognition of the other as a political and philosophical problem}

In recent years, political and philosophical debate has been revived concerning the recognition of the other. These reflections have been surfacing because of some challenging phenomena: the remarkable increase of migratory streams due to economic and social reasons, environmental disasters, and war, among others. Several theoretical developments about the issue of poverty have explained this phenomena in terms of experiences of disrespect.

However, the problem of disrespect as a form of exclusion has also been incorporated into the political agenda. Thus, problems such as affirmative action-including parliamentary quotas for women and university quotas for racial groups-have sparked discussion over the role played by the experiences of disrespect in certain social groups in the self-perception of the affected ones. For this reason, affirmative action aims to bring opportunities to these groups, in order for them to reconstruct their self-image and to progressively rebuild their self-esteem as a social group.

In the field of political philosophy, one of the early theories of justice that resurrected the problem of recognition was developed by Michael Walzer, in Spheres of Justice (Walzer: 1983). In this text, Walzer begins with the assumption that society is a distributive community, because we associate in order to share and exchange social goods (Walzer: 1983, 3). Nevertheless, these distributed social goods are not valuable in and of themselves, but rather in relationship to 
the social meanings which individuals attribute to them (Walzer: 1983, 8-9). Furthermore, these meanings have a historical character, given that they have been changing over time (Walzer: 1983, 9-10). These meanings are different, because each one constitutes an autonomous sphere of justice (Walzer: 1983, 10).

In this sense Walzer differentiates between the spheres of membership, security and welfare, money and commodities, office, hard work, free time, education, kinship and love, divine grace, recognition, and political power. Walzer deems that the recognition of the other is an autonomous sphere of justice, which has its own requirements. From this background, Walzer focuses on the struggle for recognition as an explicative factor of the conflicts for access to offices and decision-making positions (Walzer: 1983, 255-256). However, above all, this sphere must contain the requirement for the state to treat all citizens with equal concern and respect (Walzer: 1983, 277-278).

Walzer addresses the problem of recognition early in the political debate; this debate has been improved, to a large extent, by the theory of Axel Honneth, which was developed in The Struggle for Recognition (Honneth: 2003). Honneth's initial theoretical developments are grounded in an ideal of a self-fulfilled identity, which enables the subject to self-relate in terms of self-confidence, self-respect, and self-esteem (Honneth: 2003, 153-172, 194-195, 210). This demanding ideal of self-fulfillment carries normative requirements, which in turn motivate social struggles for recognition (Honneth: 2003, 258-260). The aims of these struggles, from Honneth's viewpoint, are the establishment of relationships of recognition in the fields of love, rights, and solidarity (Honneth: 2003, 262-264). Thence, social conflicts are motivated by experiences of disrespect such as the violation of the body, the denial of rights, and the denigration of ways of life (Honneth: 2003, 212-225).

Nevertheless, Honneth's theory underwent transformations as it received objections from different perspectives. This is the case in his famous debate with Nancy Fraser, published under the title of Redistribution or Recognition? (Fraser and Honneth: 2003). This debate concentrated on the problems of redistribution of goods and recognition in socio-cultural terms. Fraser argues that Honneth's theory has a psychologistic approach, insofar as it aims only to achieve a certain type of a self-fulfilled subjectivity (Fraser: 2003). Hence, Fraser defends the need to complement the requirements of recognition with the redistribution of goods and services (Fraser: 2003, 40). In this sense, Fraser states the principle 
of participatory parity, according to which it must be guaranteed to individuals that they enjoy the conditions to achieve an independency that enables them to actively participate in social life (Fraser: 2003, 47-50).

After this debate, Honneth pivoted, focusing then on problems of social justice from an institutional framework. The results of his work were published in his book Freedom's Right (Honneth: 2011). In this text, Honneth centers on the normative reconstruction of the main social institutions, in order to determine to what extent they can guarantee social freedom (Honneth: 2011, 10, 29-30). Honneth aims at evaluating the extent to which social actors could complement each other in the realization of their aims (Honneth: 2011, 86). In this sense, Honneth centers his analysis on the social spheres of family, market, and the political (Honneth: 2011, 233).

In contrast with Honneth, Charles Taylor has developed a theory of recognition that gives high value to the cultural environment in which individuals socialize (Taylor: 1992; 2001, 248-265). Hence, Taylor supports a conception of freedom in terms of an ethics of authenticity, which enables the individual to develop a situated identity from the horizon of sense of his or her culture (Taylor: 1992, 28-29; 2003; 1997, 418-428). For this reason, Taylor articulates a politics of recognition, based upon the ideal of a multicultural society (Taylor: 1992, 51-61). According to this conception of multiculturalism, cultural minorities must be especially protected, in order to make it possible for their way of life to survive (Taylor: 1992, 39-40).

These and other theoretical developments around the problematic of the recognition of the other demonstrate the political fecundity of a philosophical analysis that consists of an anthropological character. Nevertheless, this transition between such heterogeneous dimensions is a characteristic of the recognition theories. I propose that the reason for this is that the first formulation of this series of theories, which we owe to Johann Gottlieb Fichte, already integrates the fields of subjectivity, right, and the state political organization, as well as international relationships.

In this paper, I aim at demonstrating the net of these relationships in the political philosophy of the Fichte of Jena. In addition, I focus on a central aspect of Fichtean theory that is very relevant to the current debate: the right to subsistence as a constitutive right of citizenship. This right in turn implies a notable extension of the idea of freedom. In this sense, I aim to explore the conception 
of real freedom by Philippe Van Parijs, as a way to reactualize Fichte's theory from the background of the contemporary debate over justice.

\section{The recognition of the other and the constitution of subjectivity}

Fichte arrives at the problem of the recognition of the other by considering the problem of the possibility of self-consciousness. Fichte conceives self-consciousness as the self-position of the self, inasmuch as he or she is the ground of an activity which he or she attributes to him- or herself. It is a reflective activity, an "(...) activity that reverts into itself" ("eine auf sich zurückgehende Tätigkeit"), in which the I turns on him- or herself, taking him- or herself as an object (Fichte: 2000, 18; Fichte: 1796/1797, GA, I, 3, 329).

Therefore, the Fichtean concept of self-consciousness does not refer to a speculative knowledge by the I of him- or herself inasmuch as it is a practical self-consciousness. Thus, the Fichtean I is a self with volition; he or she poses aims and realizes them (Fichte: 1796/1797, GA, I, 3, 332). Thence Fichte objects to the Humean conception of the I as a bundle of perceptions. Fichte argues that the I is not the collection of perceptions that he or she suffers, but that the I him- or herself is the cause of these perceptions, that is to say, their author. This practical conception of self-consciousness also enables Fichte to criticize dogmatic metaphysics and rational psychology, according to which the I is a substance given previously to his or her activity.

According to Fichte, the I is his or her own activity. However, as any other activity, it must be explained teleologically, that is, by analyzing the aim that the agent wants to achieve with the action. It is a previous activity, which Fichte calls the proposition of the end of the action (Fichte: 1796/1797, GA, I, 3, 331). Thus, Fichte analyzes in detail the structure of the end of the action. It is a representation in which the subject sees him- or herself as the author of an action that modifies the world of the senses. Therefore, this concept of the aim contains two elements: on the one hand is the concept of the acting I, and on the other hand is the world upon which he or she wields his or her influence.

These elements imply the unavoidable requirement that the agent represents two forms of freedom. The first form is a spontaneous one, which posits the world absolutely by itself. The second form is the concept that the aim of the 
action contains too the idea of the I's freedom, but this time restricted by the laws and features of the world of senses, which are not voluntarily modifiable (Fichte, 1796/1797, GA, I, 3, 330). Given that the I is a finite one, he or she must restrict his or her freedom in order to posit the world of senses.

With this structure of the concept of the aim of the action in place, Fichte intends to explain the possibility of self-consciousness. If we, following his argumentation, aimed to explain self-consciousness from the I's freedom and spontaneity, it would seem that our demonstration would be doomed to failure. The reason is that this freedom is possible only if it is restricted by the Not-I, that is, by the laws of the world of senses, given that he or she is a finite I. Neither can self-consciousness be explained by starting from the world in which he or she acts, because it is posited by the I's spontaneous freedom, according to Fichtean idealism. From which has been previously argued, Fichte concludes that his reasoning has ended in a vicious circle, and that this explanation of self-consciousness seems to be impossible (Fichte, 1796/1797, GA, I, 3, 340).

As Jürgen Stolzenberg points out, Fichte must take another way in order to explain self-consciousness, which consists of abandoning the interpretive subjectobject scheme. Thus, Fichte adopts an approach from Stolzenberg's interpretation, grounded in intersubjectivity (Stolzenberg: 1995, 80). This means that selfconsciousness is only possible if it exists relative to another self-consciousness, with which he or she can enter in a certain relationship (Fichte: 1796/1797, GA, I, 3, 342). This intersubjective connection enables the I to become conscious of his or her capability to act freely and rationally.

This poses a particular challenge to Fichtean theory, because the other cannot be an object, given that in this case it would restrict the I's freedom, in order to adapt it to its features and laws, but would not improve it. In actuality, the other is an alter ego, but as a correlate of the I, he or she must have some form of objectuality. In other words, the I must somehow pit against (setzen) the other. Therefore, the other must restrict the I's freedom, in order to enable him or her to put his original freedom into action. Fichte solves this problem by conceiving of this intersubjective relationship as a summons (Aufforderung). In Fichte's words: we must “(...$)$ think of the subject's being-determined to be self-determining, i.e. as a summons to the subject, calling upon it to resolve to exercise its efficacy" (Fichte: 2000, 31; Fichte: 1796/1797, GA, I, 3, 342). 
Having said that, Fichte cannot conclude that the I becomes self-conscious after he or she has self-determined to action, because in this case he or she would have performed the action of setting a goal without being aware of it. This would, in turn, imply that the I exists before acting, which carries the assumption that he or she is a metaphysical substance given statically. Therefore, the I becomes conscious of him- or herself in the very moment in which he or she responds to the summons and thus self-determines to action (Fichte: 1796/1797, GA, I, 3, 343). Given that Fichte thinks the I is not a substance which exists previous to the relationship of summons, this bond appears as a prescription coming from an external impulse (Anstoss), that is to say a duty (Sollen). This means that the relationship of summons does not make reference to any feature previously possessed by the I, but to an action which must be performed by the I in the future. The prescriptive content implies, then, that the I conceives of him- or herself as a series of possibilities which are open to the future. However, this implies an important consequence that concerns the requirement that the other refuses to use coercion (Zwang), that is to say, the use of physical force to compel the I to self-determine to action.

Fichte interprets this relationship of summons as the way in which the other recognizes the I as a rational and free being. The reason is that the other cannot consistently summon the I to self-determination and simultaneously not recognize him or her as a free and rational being. We could say that through this relationship, the other somehow conveys to the I that he or she conceives of the I as a practical self-consciousness (Fichte: 1796/1797, GA, I, 3, 343), but this recognition is hypothetical until the I actually responds to the summons and confirms the recognition of the other. It is only in this way that the recognition of the other can become categorical. Therefore, even though the relationship of recognition is asymmetrical, there takes place a "free reciprocal efficacy" (freie Wechselwirksamkeit) (Fichte: 2000, 33; Fichte, 1796/1797, GA, I, 3, 344).

Given that this is a relationship of mutual recognition, Fichte cannot fall into any form of solipsism. Nevertheless, in order to protect his theory against this risk, Fichte argues that the existence of the other can be concluded from the fact that the other is summoning the I to self-determination. This is due to the fact that, if the other can recognize the I as a rational being, then at least he or she must have in mind the concept of a being of this type. This is possible only if the other is a rational being (Fichte, 1796/1797, GA, I, 3, 347). 
Furthermore, the reciprocal character of the relationship of recognition implies another relevant consequence: the principle of right (Rechtssatz), which is formulated as follows: "I must in all cases recognize the free being outside me as a free being, i.e., I must limit my freedom through the concept of the possibility of his freedom" (Fichte: 2000: 49; Fichte: 1796/1797, GA, I, 3, 358).

But the person can accomplish his or her goal only if the world of senses is structured in the same way as it was when he or she elaborated it as well as when he or she carries it out. However, the only unpredictable interference in the world of senses can come from the other person's free causality, because this type of causality is not subjected to mechanical laws. As a consequence, this possible interference in the world of senses must be neutralized by the enforcement of another person, i. e., the determination of his or her will according to rules.

The main goal of civil rights, which deal with property, is the delimitation of the citizens' spheres of action and not the mere possession of objects in the world of senses (Fichte: 1796/1797, GA, I, 4, 20; Merle: 1997a, 2000, 2001, 2006). The reason for civil rights comes from the mutual delimitation of spheres of action. Therefore, property is not the right given by the entitlement to exclude the other from the possession of something but rather the right to exclude the other from the own sphere of action (Hahn: 2003, 156).

This Copernican revolution in the conception of property implies, in turn, a shift in the conception of the relationship between freedom and the possession of objects. Freedom is not determined by the possession of some objects but instead depends on the agent's sphere of action and the adequacy of these objects as means for his proposed goals (Braun: 1991, 18).

Fichte transfers the debate about property from the classical discussion on the individual's right to appropriation of nature to a social and communitarian dimension of property (Merle: 2000, p.120; 2001, 159-161). Thence Fichte's research on property focuses on income distribution among individuals to guarantee their right to existence and the social division of labour. It is a displacement from a substantialist to a functionalist conception of wealth (Philonenko: 1984, 52-53; Hahn: 2003, 155).

Fichte intends to determine the external conditions of freedom from the analysis of the action itself. According to Fichte, when the subject sets the goal, he or she elaborates a concept of the state of affairs which he or she expects to 
find. This concept necessarily includes the requirement that the subject still exists at the moment of the realization of the action (Fichte: 1796/1797, GA, I, 4, 21). Therefore, the right to subsistence is the fundamental external condition of any free action. As Fichte concludes: "the highest and universal end of all free activity is to be able to live" (Fichte, 2000: 185; Fichte: 1796/1797, GA, I, 4, 21-22)

As a consequence, Fichte structures his conception of the state and the economy around a fundamental respect for the right of all the citizens to live from their work (Fichte: 1796/1797, GA, I, 4, 22). Given the requirement to guarantee this right, Fichte argues that the economy must be planned centrally by the state. The reason for this argument is that Fichte does not trust in the free market, having deemed it hazardous and thence incapable of guaranteeing any right.

The social division of labour is based upon the idea of a right to subsistence. Therefore, the fundamental social class is that of the producers (Producenten), who cultivate the land and breed the cattle (Fichte, 1796/1797, GA, I, 4, 26-36). However, the raw materials obtained from nature must be manufactured by the artists (Künstler), whose role is to produce the necessary tools to satisfy the vital needs (Fichte: 1796/1797, GA, I, 4, 37-38). Therefore, it is necessary that the producers exchange their products with the artists, so that they can guarantee the existence of all.

However, the producers could try to raise the prices of the raw materials they obtain by storing part of the materials, in order to provoke scarcity in the market; or, they could take advantage of the fact that their commodities are more indispensable for subsistence that the manufactures elaborated by the artists. In order to avoid this potentiality, Fichte postulates a third social class, that of the merchants (Kaufmänner) (Fichte: 1796/1797, GA, I, 4, 38-41). Their role is to regulate the exchanges between the producers' raw materials and the artists' manufactures. The Fichtean system of the division of labour implies the right to subsistence but also the duty to work (Arbeitspflicht) (Fichte: 1796/1797, GA, I, $4,23)$. Only in this way is it possible to guarantee the freedom of action for all.

One interesting contribution of the Fichtean Political Theory is the new conception of the property right, which Fichte defends. As was argued above, Fichtean property does not consist merely of possession or an exclusive right but on the delimitation of a sphere of actions which enable the citizens to pursue their goals. That means that Fichte intimately links freedom and property. This 
conception of freedom is highly significant, particularly if we take into account the debate about real freedom.

\section{The idea of a real freedom}

The Fichtean idea of freedom is a complex one, because it implies the removal of inner obstacles to action in addition to external ones. With respect to the inner forum, self-determination is possible by virtue of the recognition of the other through the relationship of summons. This indicates that Fichte conceives of freedom as the development of capabilities, because the relationship of summons has a clear pedagogical character. In this sense, the Fichtean theory is close to the conception of freedom maintained by Amartya Sen. Sen's theory is the result of the discussion of the theories of justice after Rawls. Sen protests that the theories of distributive justice have a deficit of empirical basis, because they do not take into account that goods or resources must be converted into the effective capability to pursue reasonable goals (Sen: 1985, 1990, 1993, 1999).

Fichte's Theory is conceptually placed in the same sphere as Sen's Philosophy, given that Fichte conceives of property in terms of capabilities to act and not of the mere possession of objects, as it was argued in the previous section. Fichte states that a just state is at the service of the development of citizens' consciousness, i. e., of their awareness of their capability of agency. If the other does not recognize a subject as being capable of self-determination to action, then this subject will not be able to establish any kind of relationship of right with others.

If the individual cannot enter into a relationship of right, he or she will neither be able to delimit his sphere of action nor leave an equal sphere for others. Therefore, he or she will not have any sense to think of a just redistribution of goods and resources. The body is the linking point between the consciousness of one's own capabilities and the need for certain goods, to realize the proposed aims. The will makes it possible for an agency to have an influence directly over the body, inasmuch as it is an articulated natural product. The body, in turn, could have influence on the world of senses if it has at its disposal the necessary means for its goal. This implies the universal right to the possession of certain goods and resources. Only in this way can the sphere of free actions be concretized, which makes agency and right possible. 
In this sense, the Fichtean argumentation is analogous to Amartya Sen's, given that in both theories, the capability of agency is prerequisite to the distribution of resources, being the foundation of the idea of justice. Therefore the Fichtean idea represents an important antecedent of the debate about distributive justice. Nevertheless, Sen's original approach does not take into account the specific problems of distributive justice, leaving his theory incomplete. In contrast with Sen, the conception of freedom developed by Fichte integrates requirements of the redistribution of goods and resources. In this sense, this idea complements approaches such as Sen's Development of Capabilities.

Fichte thinks that property is an external condition of freedom, given that freedom of action is impossible if the agent was not guaranteed the right to subsistence. Therefore, Fichte introduces the requirement that the state guarantees access for all citizens to a set of goods and resources. This is the only way to give effect to the contract of citizenship.

I think that, in order to grasp the theoretical potential of the Fichtean idea of freedom, it is useful to reconstruct Philippe Van Parijs's foundation of the idea of real freedom. Jean Christophe Merle has focused on Van Parijs's theory in a book concerning the problem of justice in Fichte, which is an important antecedent of this type of research. However, in this book Merle, does not intend to compare both theories (Merle: 1997b, 223-226). From my viewpoint, the idea of real freedom can show us another facet of Fichtean political philosophy, which evidences the theory's relevance. The point of contact between both theories is the close relationship between freedom and property. This explains Van Parijs's objection to the liberal conception, which is understood as mere formal freedom. Nevertheless, Van Parijs defends individual liberties and objects to the several forms of positive liberty. In this sense, Van Parijs is in line with the Fichtean idea of freedom as self-determination of the agent. The Fichtean natural right endeavors to exclude all kinds of moral assumptions, in order to build a theory which is suitable even to immoral people. Therefore, Fichte intends to guarantee all subjects the freedom to decide for themselves how to conduct their lives.

These conceptual elements common to both theories call for closer attention to Van Parijs's idea of freedom. This philosophy could be better understood if we took into account that its ultimate goal is to determine the ideal of a just society, which must fill the void left by capitalism as well as socialism. This conception of justice is based upon a certain idea of freedom, which is the result of the rejection of other candidates. 
In the first scenario, Van Parijs puts into question one version of the notion of positive liberty, which implies that all citizens must enjoy the same quantity of power, in order to influence certain decision-making processes. That means intervening in the private lives of individuals and forcing them to follow certain norms. This procedure severely restricts individual liberties, which is evident if we compare a community that decides that all of its members must reduce the size of their noses to a community in which the same subjects are allowed to decide to do so or not. Van Parijs argues that this conception of positive liberty confuses freedom with power, and therefore it cannot grasp the great difference that exists between both mentioned situations.

We see that difference in the second scenario, in which a negative liberty is guaranteed: we are not at the mercy of the other's opinions when making decisions which involve the inner forum. In other words, the idea of positive liberty (to which Van Parijs objects) does not imply respect for self-ownership, conceived as the possibility of doing whatever oneself might want with one's own person (Van Parijs: 1995, 7-9). As it was argued before, in Fichtean theory self-ownership is a central element of freedom, understood as the subject's selfdetermination. While arguing against the idea of positive liberty, Van Parijs harmonizes with Fichtean methodological individualism, which starts from the subject taken separately and not from the community as a whole.

This methodological approach can also be seen in Van Parijs's objections against the type of positive liberty that is based upon self-determination of the political community against external threats. According to Van Parijs's argument, this idea provokes severe restrictions of freedom, such as in the case of compulsory military conscription or repression of minorities in order to improve the cultural homogeneity of the community. For this reason, Van Parijs prefers to talk about a society of free individuals rather than about a free society, in the same line as Fichte (Van Parijs: 1995, 15-17).

Therefore, political liberties and popular sovereignty are instrumental but not an end in themselves, given that they aim to protect individual liberties. Thus, Van Parijs deems that the idea of positive liberty is compatible with the negative liberty, so long as we understand the latter as the absence of external constrictions on action. Furthermore, Van Parijs argues that the one or the other concept of liberty must be emphasized depending on the context of application. In reality, the idea of positive liberty objected to by Van Parijs is one that embodies a kind of moral perfectionism, that is, the idea that what makes a society 
just is determined only by a substantive idea of the good life (Van Parijs: 1995, 17-18, 28-29). As it was argued before, Fichte makes the same argumentative movement, insofar as he articulates his idea of freedom independently of moral assumptions. Fichte's reason for doing so is that he intends to build a theory of right that is ecumenical enough to be valid even for those who do not consciously hold a substantive moral conception.

Van Parijs argues that, if we understand freedom as the possibility to do whatever we may want to do in the present moment, we could not avoid objection to the idea of the happy slave. This argument posits that it could happen that, if we were enslaved, we would adapt our preferences to what we actually could do, which would be very limited. According to this chain of reasoning, it is counter-intuitive to conceive of freedom as a mere manipulation of preferences.

From this background, Van Parijs examines the criterion of authenticity, which requires that the subject shapes his or her own preferences in order to act freely, and is not influenced by any exogenous preference during this process. According to Van Parijs, this criterion also does not solve the objection to the happy slave, because the agent can shape his or her own preferences so that they become adapted to oppressive circumstances. On the other hand, it is also necessary to have some second-order desires which are broader, in order to decide which of the examined preferences is authentic. Given that it is not possible to fall in an infinite regress, sooner or later we must deem some desires as authentic and others as exogenous.

As a consequence of the former research, Van Parijs defines freedom as the ability to do whatever one might want in the absence of coercion. This definition includes a counterfactual, which gives this concept of freedom a broader scope than that of a merely negative liberty. The reason is that the agent could be able to realize certain preferences in the present moment, but this does not mean that he or she could satisfy other preferences in case he or she would intend to do so. This means that Van Parijs's idea of freedom requires taking into account a broader scope of factors, conditionings, and situations than what's present in a simple version of negative liberty. We must not deem the possibilities of action from the current psychological dispositions of the agent but rather imagine possible scenarios, even though they will never take place.

Thence, this philosopher concludes that the objection to the happy slave has been solved. Given that this concept of freedom requires taking into account 
the preferences that the agent could probably have, and not only those that he or she is experiencing in the present moment, it cannot be said that the agent is free if he or she is being enslaved or if he or she suffers under extremely oppressive circumstances. The reason is that if the agent is absolutely at the mercy of the other, and has thus shaped his or her preferences in order to adapt to the current possibilities of action, he or she would not be able to satisfy his or her preferences in a different scenario. For example, a slave can actually desire to have his or her freedom of movement restricted, to be unable to leave his or her room, to express his or her opinions whenever he or she would want, to change his or her diet, etc. In other words, this slave could perhaps be free to satisfy his or her current preferences, but would not be able to do so if he or she had other goals.

Having said that, Van Parijs argues that this definition is able to overcome the problems posed by the criterion of authenticity, given that it enables the agent to perform a wide range of actions, which are not necessarily subjected to any normative pattern (Van Parijs: 1995, 17-20). This implies that this conception of freedom does not require any evaluation of the quality or the character of one's own preferences. The central feature of this conception of freedom does not require the agent to hierarchize his or her desires, but rather to take into account which possibilities to realize which preferences are open to him or her. This intellectual operation demands the use of the imagination for modeling several constellations of factors and conditions of different types.

In the same line, the Fichtean idea of freedom is conceived in these terms, given that it requires the agent to be able to realize a certain range of goals. The agent must be capable of representing him- or herself acting in different contexts. Ownership of the means of subsistence assures the effective freedom of action. Therefore, the Fichtean theory includes a counterfactual too, inasmuch as it makes reference to several possible scenarios of action.

As in the Fichtean theory, the counterfactual present in Van Parijs's idea of freedom requires a series of guarantees, which enable the agent to reasonably expect to satisfy other preferences which he or she may eventually have. These are a set of reassurances against the use of physical force or the advantages anyone might take in a situation of asymmetrical economic resources, as well as against the power anyone could have to decide the employment situation of others. From the background of Van Parijs's philosophy, that system of rights includes the freedoms of conscience and action, as well as the rejection of compulsory 
military conscription, the tax for talents, the personal capabilities, and-above all—the institution of slavery.

Having said that, this conception has several limitations, given that the system of rights and self-ownership integrates what Van Parijs calls "formal freedom." In order to achieve "real freedom," a third component must be added to this set: opportunity. In a system of formal freedom, it could be stated that someone is free to take — or not take—an oppressive job to avoid starving. To arrive at this conclusion, it must be assumed that this person's situation is a product of respect for the rights of property in the community of belonging, and that his or her freedom of thought and action are sufficiently protected. In this sense, it could be stated that a very poor person is free to go on a cruise through the Caribbean or to buy a television channel. Therefore, the concept of formal freedom implies clearly counterintuitive consequences.

The component of opportunity, then, makes it possible to avoid this type of implication, given that it introduces the dimensions of power, capability, means, money, etc. Thus, the idea of opportunity articulates the conception of real freedom, which involves considering the external conditionings of a free action. Nevertheless, the idea of real freedom also involves the inner obstacles for the agent when trying to realize preferences, such as certain physical handicaps or a lack of education in certain capabilities, addiction issues, etc. (Van Parijs: 1995, 22-24).

As it was argued above, Fichte also conceives of freedom in terms of access to certain goods and resources. Fichte cannot state that an individual could initiate courses of actions without permission of the others to exclusively use certain goods and prerogatives. He deems that, in the latter case, the individual would be unable to modify his or her environment and to realize his or her goals, given that his or her will would be able to move his or her body but would not have the possibilities for action at his or her disposal.

According to Van Parijs, a society of free individuals is a society in which a system of rights and self-ownership are efficaciously guaranteed, and each and every one of its members has the broadest possible opportunity to satisfy any preference which he or she may have (Van Parijs: 1995, 25-29). In order to guarantee real freedom, it must especially take into account the situation of the most disadvantaged. This requirement can be fulfilled, according to this theory, by the leximin criterion of opportunities. This criterion prescribes that, given 
a certain institutional disposition, those people who enjoy fewer opportunities must not be in a worse position that any other feasible disposition.

Consequently, Van Parijs advocates for implementing a system that provides the highest basic sustainable income for all citizens, in order to make real freedom effective. Nevertheless, this increase of income is not necessarily oriented to maximize the consumption of goods. The reason is that real freedom is the capability to choose the lifestyle one may want, even when this means to abandon a career for economic success and consumerism. Furthermore, real freedom makes it possible for those who do not agree with wage labor to quit the work system. As a result of the former chain of reasoning, Van Parijs concludes that: "A basic income, in other words, is an income paid by the government to each full member of society (1) even if she is not willing to work, (2) irrespective of her being rich or poor, (3) whoever she lives with, and (4) no matter which part of the country she lives in" (Van Parijs: 1995, 35; see Raventós: 1999, 53-56).

As it was argued above, the first form of unconditionality aims to guarantee that individuals are able to choose the lifestyle they would want, which could potentially include the rejection of all forms of wage labor. This statement clearly differs from the Fichtean idea of a "duty to work" (Arbeitspflicht). The reason is that Fichte begins with the assumption that the only way to produce and distribute wealth must occur in the context of a social division of labour. On the contrary, Van Parijs cannot assume a division of labor which is centrally planned by the state, because he deems the free market as an indispensable institution. On the other hand, Van Parijs is aware that the market produces injustices and that it therefore must be regulated.

The foundation of the second form of unconditionality makes reference to the threat to real freedom that is the application of a conditional income, given that it requires verification that the applicants are poor. According to Van Parijs, it might happen that, during the process of the required paperwork, an individual lacks the means to make his or her needs meet. The same issue occurs when citizens must periodically renew their conditional income. The second form of unconditionality also frees subjects from the trap of unemployment. This oppressive situation happens when those who receive a conditional income in the form of unemployment insurance are afraid of finding a job, because it usually is insecure and pays worse than unemployment insurance. Furthermore, access to a job leads to the loss of a conditional income, and the renewal of the aforementioned paperwork after losing the job with its undesirable consequences. 
The third and fourth forms of unconditionality intend for the citizen to have real freedom in terms of choosing to live alone or in a community, in the city or the country, choices which require an unconditional income (Van Parijs 1995: 35-38; Raventós: 1999, 95-99, 134). Therefore, the unconditional income must provide the individual with freedom of action, which depends on the amount required. For example, the individual might need more money if he or she lives in a family with handicapped members, or if he or she lives alone. Furthermore, he or she might need more money when living in a city than in the country.

Finally, the income would be paid monthly according to competitive market prices. The option for monthly payments — and not for an initial endowment-is grounded in the need to protect citizens from wasting the initial endowment. Thus, Van Parijs intends to guarantee the citizen's freedom to make mistakes in the spending of their monthly payment without losing a relevant part of their set of opportunities (Van Parijs: 1995, 45-48).

As a result of the above arguments, it is evident that freedom as a set of opportunities has elements in common with the Fichtean conception of a right to subsistence. In both theories is a defense of the statement that citizens must have their basic needs satisfied. Furthermore, for both authors, the constitutive rights of citizenship involve several spheres, including the market. In sum, I think that Fichtean theory can enrich the current debate about the problem of freedom, and as a consequence bring a little light to the difficult times in which we are living. 


\section{Bibliography}

Braun, J. (1991). Freiheit, Gleichheit, Eigentum. Grundfragen des Rechts im Lichte der Philosophie J.G. Fichtes, Tübingen: J.C.B. Mohr (Paul Siebeck).

Fichte, J. G. (1796/1797). Grundlage des Naturrechts nach Principien der Wissenschaftslehre. Quoted with the abbreviation GA, volume, and page number according to the edition: Laut, R. у JаСов, H. (eds.) (1962 ss.). Johann Gottlieb Fichte: Gesamtausgabe der Bayerischen Akademie der Wissenschaften. Stuttgart-Bad Cannstat: frommann holzboog.

(2000). Foundations of Natural Right, Baur, M., (trans.), Neuhouser, F. (ed.). Cambridge: Cambridge University Press.

Fraser, N. and Honneth, A (2003). Umverteilung oder Anerkennung? Eine politischphilosophische Kontroverse. Frankfurt: Suhrkamp.

Fraser, N. (2003). "Soziale Gerechtigkeit im Zeitallter der Identitätspolitik. Umverteilung, Anerkennung und Beteiligung" in Fraser, N. y Honneth, A. Umverteilung oder Anerkennung? Eine politisch-philosophische Kontroverse. Frankfurt: Suhrkamp, pp. 13-128.

Hahn, K. (2003). "Die Relevanz der Eigentumstheorie Fichtes im Zeitalter der Globalisierung unter Berücksichtigung Proudhons und Hegels“. Fichte-Studien, 24, pp. $155-163$.

Honneth, A. (2003). Kampf um Anerkennung. Zur moralischen Grammatik sozialer Konfikte. Frankfurt: Suhrkamp.

(2011). Das Recht der Freiheit. Frankfurt: Suhrkamp.

Merle, J.-CH. (1997a). "Notrecht und Eigentumstheorie im Naturrecht, bei Kant und bei Fichte". Fichte-Studien 11, pp. 41-61.

(1997b). Justice et progrès. Paris: Presses Universitaires de France.

(2000). «Le droit de proprieté chez Fichte» in Bienenstock, M., Crampe-CasNABEt, M. (eds.). Dans quelle mesure la philosophie est pratique. Fichte, Hegel. Avec la collaboration de Jean-Francois Goubet. Fontenay/Saint-Cloud: Ens Éditions, pp. 159-172.

(2001). „Eigentumsrecht (\$\$ 18-19)“, in MerLe, J.-Ch. (ed.). Johann Gottlieb Fichte. Grundlage des Naturrechts. Berlin: Akademie Verlag, pp. 159 - 172.

(2006). „Johann Gottlieb Fichte, Der geschlossene Handelstaat (1800)“, in BroKKER, M. (ed.). Geschichte des politischen Denkens. Frankfurt am Main: Suhrkamp, pp. 387-402.

Philonenko, A. (1984). L'Oeuvre de Fichte. Paris: Libraire Philosophique Vrin. 
Raventós, D. (1999). Los derechos de existencia. La propuesta del Subsidio Universal Garantizado. Barcelona: Ariel.

SEn, A. K. (1985). "Well being, Agency and Freedom: The Dewey Lectures 1984". The Journal of Philosophy 82, pp. 169-221.

_ (1990). "Justice: Means versus Freedoms". Philosophy and Public Affairs 19, pp.111121.

(1993). "Markets and Freedoms: Achievements and Limitations of the Market Mechanism in Promoting Individual Freedoms", Oxford Economic Papers, 45, pp. 519-541.

(1999). Development as Freedom. New York: Albert A. Knopf.

Stolzennerg, J. (1995). "Fichtes Begriff des praktischen Selbstbewusstseins", in Hogrebe, Wolfram, (1995). Fichtes Wissenschaftslehre. 1794. Philosophische Resonanzen. Frankfurt am Main: Suhrkamp, pp. 71-95.

Taylor, Ch. (1992). "The Politics of Recognition", in Gutmann, A. Multiculturalism and "The Politics of Recognition". Princeton: N. J., Princeton University Press.

_ (1997). "What's wrong with negative liberty?" in Goodin, R. and Pettit, P. (eds.). Contemporary Political Philosophy. An Anthology. Oxford: Blackwell Publishers.

_ (2001). Sources of the Self. The Making of Modern Identity. Cambridge Massachusetts: Harvard University Press.

_ (2003). The Ethics of Authenticity, Cambridge, Massachusetts and London, Harvard University Press.

VAN PARIJs, P. (1995). Real Freedom for all. What (if anything) can justify capitalism? Oxford: Clarendon Press.

Walzer, M. (1983). Spheres of Justice. A Defense of Pluralism and Equality. New York: Basic Books.

Recibido: 28/12/2017

Aceptado: 8/05/2018

Este trabajo se encuentra bajo una licencia de Creative Commons ReconocimientoNoComercial-SinObraDerivada 4.0

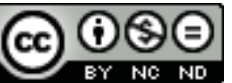


